\title{
A ENCENAÇÃO DOS SONHOS: IMAGENS DE FREUD E DE BENJAMIN
}

Alessandra Affortunati Martins Parente

Alessandra Affortunati

Martins Parente

Psicanalista, doutoranda em Psicologia Social (Ipusp), mestre em Psicologia Clínica pela PUC-SP, psicóloga (PUCSP) e bacharel em Filosofia pela FFLCH-USP.
RESUMO: O texto procura tecer alguns elos entre o modo como se dá a formação dos sonhos para a psicanálise freudiana e a maneira pela qual o trabalho com cinema se processa na visão de Walter Benjamin. A aproximação entre sonhos e cinema na visão dos autores mencionados visa analisar o modo como a subjetividade se constitui na modernidade, apontando tanto para questões da vida psíquica dos sujeitos, como também para uma perspectiva histórico-política mais abrangente.

Palavras-chave: Sonhos, cinema, psicanálise freudiana, Walter Benjamin.

ABSTRACT: The dream's staging: images of Freud and Benjamin. The text seeks to make some links between the way the formation of dreams is to Freudian psychoanalysis and the way of working with film takes in the vision of Walter Benjamin. The rapprochement between dreams and movies in the authors mentioned aims to examine how subjectivity is constituted in modernity, pointing both to issues of psychic life of individuals but also to an historical and political vision.

Keywords: Dreams, movie, Freudian psychoanalysis, Walter Benjamin. 
C omo bem observa Rivera "cinema e psicanálise são rigorosamente contemporâneos" (2008, p.11), pois, no mesmo ano em que ocorre a publicação dos estudos sobre histeria (1895), os irmãos Lumière fazem as primeiras projeções públicas em Paris. Não só isso, mas ao mesmo tempo em que as apresentações dos irmãos Lumière são feitas, Freud está escrevendo sua análise do emblemático sonho da injeção de Irma. As aproximações entre cinema e psicanálise não param por aí. Como, evidentemente, não será possível abordá-las todas, este trabalho faz um recorte da psicanálise, dando enfoque à obra freudiana $A$ interpretação dos sonhos (1900/1996) e, no caso do cinema, o texto de Walter Benjamin A obra de arte na era de sua reprodutibilidade técnica (1935-6/1994), assim como suas teses Sobre 0 conceito de história (1940/2005) conduzirão a discussão. A visão dos autores sobre esses diferentes temas - sonhos e cinema — será aproximada, de modo que a subjetividade da modernidade possa ser analisada do ponto de vista psíquico e por um viés histórico-político.

Assim como a obra freudiana, os textos de Benjamin denotam uma ambiguidade em relação às conquistas da modernidade, que pode ser sintetizada na seguinte frase do filósofo: "Nunca há um documento da cultura que não seja, ao mesmo tempo, um documento da barbárie." (BENJAMIN, 1940/2005, p.70). O tempo da modernidade transcorre em alta velocidade, erguendo atrás de si um acúmulo de ruínas e fragmentos órfãos de experiência. Imerso num tempo descontínuo prenhe de um excesso de estímulos — vividos como choques o homem moderno ocupa-se em defender-se e abandona rastros desencarnados, isto é, desprovidos de história. O transeunte das cidades modernas circula por espaços fantasmagóricos nos quais os objetos, a arquitetura, as moradias não tocam um tempo remoto, mas são eternamente novos. Ele está deslumbrado diante das últimas novidades e fica ocupado em responder às demandas do capital no mesmo ritmo das máquinas, abdicando da possibilidade de ter experiências. Diante deste panorama, Benjamin vê o cinema de forma paradoxal: ao mesmo tempo em que este ressuscita imagens relegadas ao esquecimento, reitera um modo de percepção incapaz de restaurar um olhar que convoque à experiência. Assistir a um filme é submeter-se aos choques que as diferentes cenas impõem ao espectador, exigindo deste uma disposição distraída para que seja capaz de acompanhar a intermitência entre os elos do enredo. Nas palavras do filósofo:

"A técnica submeteu, assim, o sistema sensorial a um treinamento de natureza complexa. Chegou o dia em que o filme correspondeu a uma nova e urgente necessidade de estímulos. No filme, a percepção sob a forma de choque se impõe como princípio formal. Aquilo que determina o ritmo de produção na esteira rolante está subjacente ao ritmo da receptividade, no filme." (BENJAMIN, 1939/1997, p.125) 
Na psicanálise freudiana, a desconfiança diante dos avanços do processo civilizatório, que na modernidade alcançaram planos antes insuspeitos, pode ser evidenciada, sobretudo, no texto Mal-estar na civilização. Freud (1930/1996) argumenta que, em nome do processo civilizatório, o homem foi obrigado a renunciar a grande parte de suas pulsões sexuais e agressivas. Tal renúncia ocorreu por meio de recalque, o qual não é inócuo para a saúde psíquica dos indivíduos. A severidade da censura internalizada pelos sujeitos sob a forma de superego resulta em mal-estar permanente. O homem se vê compelido a alcançar todas as ambições da ética civilizatória de amor ao próximo, ordem, limpeza, amor sexual comedido e restrição à agressividade. Entretanto, os vestígios dos impulsos insatisfeitos relegados ao porão são impertinentes, fazendo também suas exigências. O homem civilizado é refém deste conflito entre exigências do superego e reivindicações do id. Assim como Walter Benjamin trata dos escombros da história condenados ao esquecimento, Freud traz à luz os aspectos desdenhados ou até repudiados pelo processo civilizatório: sexualidade infantil, sonhos, desejos de morte e incesto, atos falhos, chistes. Ao abordar esses temas, concede-lhes novo estatuto, tomando, como Benjamin, a tarefa de "escovar a história a contrapelo" (BENJAMIN, 1940/2005, p.70) para redimir os restos considerados absurdos ou simplesmente banidos do discurso corrente.

O cinema é pensado por Benjamin como uma das formas de trazer para a consciência elementos que, sem ele, permaneceriam esquecidos ou desconhecidos. Em seu clássico texto sobre o cinema, lemos: "O cinema introduziu uma brecha na velha verdade de Heráclito segundo a qual o mundo dos homens acordados é comum, o dos que dormem é privado.” (BENJAMIN, 1935-6/1994, p.190). A referência a temas da psicanálise, como os sonhos, não é apenas indireta no texto de Benjamin. Segundo o filósofo, “o cinema enriqueceu o nosso horizonte de percepção com métodos que podem ser ilustrados pela teoria freudiana” (BENJAMIN, 1950/1983, p.22). Para esclarecer os efeitos do cinema na percepção humana, Benjamin recorre ao texto Psicopatologia da vida cotidiana (1901/1996). Argumenta que, antes do advento da psicanálise, um lapso cometido ao longo de uma conversa dificilmente era notado. Com a análise de atos falhos e chistes, este fato alterou-se, dando margem a uma investigação por caminhos antes inexplorados. A amplitude da percepção óptica e acústica no cinema teve como consequência um aprofundamento semelhante da percepção. Sua revolução localiza-se nos grandes planos, no realce de detalhes antes imperceptíveis, na exploração de lugares banais com uma direção surpreendentemente objetiva, aumentando a extensão de nossa compreensão sobre as imposições que regem a vida e ampliando o alcance do campo de ação humano. Nas palavras de Benjamin: 


\begin{abstract}
“Nossos cafés e nossas ruas, nossos escritórios e nossos quartos alugados, nossas estações e nossas fábricas pareciam aprisionar-nos inapelavelmente. Veio então o cinema, que fez explodir esse universo carcerário com a dinamite dos seus décimos de segundo, permitindo-nos empreender viagens aventurosas entre as ruínas arremessadas à distância. O espaço se amplia com o grande plano, o movimento se torna mais vagaroso com a câmara lenta. É evidente, pois, que a natureza que se dirige à câmara não é a mesma que se dirige ao olhar. A diferença está principalmente no fato de que o espaço em que o homem age conscientemente é substituído por outro em que sua ação é inconsciente.” (1935-6/1994, p.189)
\end{abstract}

As novas técnicas inauguram, portanto, dimensões inexistentes aos olhos naturais dos homens. Espaços preenchidos de forma consciente são substituídos por outros antes invisíveis. Se o caminhar de um homem podia ser observado, após o cinema as sutilezas de cada um dos passos podem ser apreendidas através da câmera lenta. O simples foco nos pés em movimento nos traz um mundo inédito e cheio de detalhes. Benjamin alude a alguns gestos que antes do cinema eram insignificantes aos nossos olhos: pegar um isqueiro, por exemplo. O fato de elevá-lo até a boca e acendê-lo diante do cigarro preso entre os lábios torna-se uma cena tão importante quanto a de um acidente de carro. Eventos aparentemente sem importância na vida passam a ocupar lugar de destaque nas telas de cinema, e esta nova forma de percepção evidentemente se estende para fora delas. A câmera recorta, mergulha em detalhes, sobe, desce, isola, interrompe, alonga, acelera, levando-nos "a experiência do inconsciente óptico, do mesmo modo que a psicanálise nos abre a experiência do inconsciente pulsional.” (BENJAMIN, 1935-6/1994, p.189).

Assim como o cinema, a psicanálise ampliou o alcance da percepção diante das imagens oníricas. O sono, terreno fértil para aventuras tresloucadas, conduz a uma trama na qual se condensam e deslocam restos diurnos, lembranças infantis e elementos de nosso repertório psíquico. Nos sonhos, o desenho de uma bizarra figura mostra-nos que mais de uma personagem presente em nossas vidas pode, por razões inconscientes, encarnar um único corpo de forma mesclada. Uma face se conjuga com diferentes traços de outra, uma pessoa aparece com outro corpo, um detalhe - como um bigode ou uma barba - é acrescentado ao rosto de uma mulher conhecida. Por meio da psicanálise, a mistura pode ser decomposta até que se chegue à lógica inconsciente utilizada para que tal composição tenha se tornado possível. As imagens lacônicas e fragmentárias, próprias dos enredos oníricos, são, na verdade, elementos aglomerados, não aleatoriamente, mas no interior desta lógica inconsciente, que a psicanálise visa reconstituir. Esta tarefa ocorre por meio de associações que vão mostrando pouco a pouco como elementos ou afetos infantis, restos diurnos, diferentes figuras e palavras dispersas 
foram congregados ou invertidos nas cenas de um sonho, aparentemente sem sentido. Assim, a interpretação é um ir e vir que conduz as associações "de um elemento do sonho para vários pensamentos do sonho e de um pensamento do sonho para vários elementos do sonho” (FREUD, 1900/1996, p.310). Estes se combinam para concentrar toda a massa de pensamentos oníricos, e cada um dos fragmentos possui múltiplas facetas determinadas por eles.

O sonho da injeção de Irma mostra o trabalho da condensação: na figura de Irma concentram-se inúmeras mulheres, da filha à esposa, passando por outra criança e uma instigante mulher, que Freud deseja ter como paciente em seu lugar. No trabalho de condensação há uma construção de figuras coletivas e compostas, composição de palavras e imagens, nomes ou lugares. Condensar, por conseguinte, significa reunir elementos aparentemente sem qualquer vínculo nítido para a lógica consciente, de modo que os anseios inconscientes possam se manifestar sem afetar as restrições impostas pela outra instância psíquica. Este trabalho psíquico pode ser comparado à editoração ou montagem de um filme. Ali, as várias partes que obedecem à lógica da filmagem são depois recortadas e reunidas em outra trama, que resulta no produto visto pelos espectadores. A propósito do cinema soviético, Bernardet escreve:

“Os soviéticos [...] fundamentaram seu trabalho na seleção e na montagem, mas com extrema valorização na montagem. Para eles, montagem não é reconstrução do real imediato, mas construção de uma nova realidade. Uma realidade propriamente cinematográfica. Filmo o rosto de uma mulher, a mão de outra, o pé de uma terceira, assim por diante, e monto: o espectador vê uma mulher, perfeitamente convincente, só que ela não existe, é uma invenção do cinema criada pela montagem.” (1980/2009, p.48)

Outra estratégia bastante comum que evidencia a ilusão propiciada pelo cinema é o trabalho do dublê. O espectador assiste à cena que tem a personagem sempre com a sensação de continuidade por tratar-se da mesma pessoa em diferentes situações. No entanto, revelar os procedimentos da filmagem também mostra como uma figura é substituída por outra, sempre transparecendo ser a mesma na tela.

Além da condensação, o deslocamento representa papel de destaque no trabalho onírico. Ele pode ser percebido, grosso modo, pelos elementos que ganhavam foco no conteúdo manifesto do sonho, mas que nos pensamentos do sonho pareciam ter um significado bem menos relevante. Não só isso, mas os pensamentos oníricos distanciam-se de forma óbvia do conteúdo dos sonhos, e ambos - conteúdo manifesto dos sonhos e pensamentos oníricos - aparentemente caminham em direções em que não há encontro. Só na decomposição 
de um sonho é possível notar que um elemento de grande intensidade na trama onírica tem uma dimensão irrelevante para os pensamentos oníricos e vice-versa. Segundo Freud (1900/1996), parece ser evidente quais elementos dos pensamentos do sonho têm mais alto valor psíquico. Na formação de um sonho, contudo, tais elementos essenciais, cobertos de grande interesse, são reposicionados e ganham valor irrisório se contrastados ao lugar dado a outros componentes cujo pequeno valor é claro nos pensamentos do sonho. As representações que se destacam dentre os pensamentos do sonho decerto obedecem a sua recorrência, mas no trabalho do sonho pode justamente ocorrer o inverso: a ênfase recai sobre os atributos pouco significativos para os pensamentos oníricos.

Em suma, na encenação onírica opera uma força psíquica que visa desalojar os elementos atrelados a um alto valor psíquico e, por outro lado, conceder, por meio da sobredeterminação, intensidade aos elementos de baixo valor psíquico. Nas palavras de Freud: "ocorrem uma transferência e deslocamento de intensidade psíquica no processo de formação do sonho, e é como resultado destes que se verifica a diferença entre o texto do conteúdo do sonho e o dos pensamentos do sonho" (1900/1996, p.333).

Assim, o que é alcançado no processo de deslocamento é um conteúdo que não mais se assemelha ao núcleo dos pensamentos do sonho; estes figuram de forma distorcida e tecem de maneira camuflada a trama do desejo inconsciente. A censura que uma instância psíquica da mente exerce sobre a outra ocorre sempre como um modo de defesa. Como tal censura deve ser burlada, em nome da satisfação de uma das instâncias envolvidas, o deslocamento e a condensação aparecem como manobras de encobrimento e satisfação do desejo inconsciente.

Neste sentido, o sonho é uma espécie de escrita psíquica formada não por palavras, mas por imagens que encenam um roteiro apenas identificado pelo trabalho de interpretação. Para Freud, uma expressão insípida e abstrata dos pensamentos oníricos é substituída por uma expressão pictórica e concreta. O psicanalista afirma:

“[...] um pensamento onírico não é utilizável enquanto expresso em forma abstrata, mas uma vez tenha sido transformado em linguagem pictórica, os contrastes e identificações do tipo que o trabalho do sonho requer, e que ele cria quando já não estão presentes, podem ser estabelecidos com mais facilidade do que antes entre a nova forma de expressão e o restante do material subjacente ao sonho." (FREUD, 1900/1996, p.372)

A redução de "pensamentos oníricos dispersos à expressão mais sucinta e unificada possível”, pode ocorrer a fim de que haja "transformações verbais apropriadas para os pensamentos isolados” (FREUD, 1900/1996, p.372). Vemos, 
portanto, que as imagens concretas reivindicam novas palavras. As imagens oníricas são vestígios ressuscitados de um passado inerte, que, ao ganharem vida, vêm habitar as noites de sono de forma intensa e mesclada com temas recentes. Para Benjamin, a imagem também ocupa um lugar relevante no encontro entre passado e agora. Diz o filósofo:

“Não se deve dizer que o passado ilumina o presente ou que o presente ilumina o passado. Uma imagem, ao contrário, é onde o Antigo encontra o Agora em um raio para formar uma constelação. Em outras palavras, a imagem é a dialética parada. Porque, enquanto que a relação do presente com o passado é puramente temporal, contínua, a relação do Antigo com o Agora é presente e dialética: não é algo que se escoe, mas uma imagem descontínua. Somente as imagens dialéticas são imagens autênticas [...] e o lugar onde são encontradas é a linguagem.” (BENJAMIN, apud MURICY, 1999, p.209)

Nota-se que também para Benjamin o tempo não é linear, mas um entrecruzamento de fragmentos remotos e presentes. Além disso, a menção feita às imagens concretas remete a outro ponto de encontro entre os autores aqui tratados: o materialismo-histórico-dialético. Para Safatle (2008, p.116), Freud, ao dar ênfase aos processos empíricos da constituição subjetiva, torna-se um materialista por excelência, escapando de qualquer tentativa de explicação transcendental. O caráter material da psicanálise, identificado por alguns autores, não se limita, no entanto, a uma visão marxista, que o circunscreveria às relações de trabalho ou à mercadoria. Até mesmo as palavras têm, na obra freudiana, um caráter material, remetendo a situações concretas de tempos remotos da vida psíquica. Segundo Freud, as palavras recuperam sua materialidade nos sonhos e os termos concretos transpõem para estes sua riqueza de associações. Cada um dos termos analisados em sua concretude evoca sentidos esquecidos na linguagem corrente. É interessante notar que, ao capturar tal materialidade das palavras, os sonhos, além de retomarem a multiplicidade de sentidos contida em um único termo, apontam para a sua ambiguidade, tornando alguns significados opostos aos originalmente supostos. Freud assinala a ambiguidade das palavras no seguinte trecho da Interpretação dos sonhos:

\footnotetext{
“Não há porque nos surpreendermos com o papel desempenhado pelas palavras na formação dos sonhos. As palavras, por serem o ponto nodal de numerosas representações, podem ser consideradas como predestinadas à ambiguidade. [...] Quando uma palavra ambígua é empregada em lugar de duas inequívocas, o resultado é desnorteador; e quando nosso sóbrio método cotidiano de expressão é substituído por um método pictórico, nossa compreensão fica paralisada [...]” (1900/1996, p.372-3)
} 
Freud declara que ao interpretar os sonhos é difícil saber se ele deve ser tomado num sentido positivo ou negativo (como uma relação antitética), se deve ser interpretado historicamente (como uma lembrança) ou de modo simbólico, ou se a interpretação deve depender de seu enunciado. De forma análoga, Benjamin considera que a ambiguidade é figuração dialética retida. Assim, a imagem dialética é, para ele, imagem de sonho. Nas palavras do autor: "A ambiguidade é a manifestação figurada da dialética, a lei da dialética detida. Essa detenção é utopia e a imagem dialética é, portanto, uma imagem de sonho." (BENJAMIN, citado por ROCHLITZ, 2003, p.232). Assim, Benjamin também amplia o materialismo-dialético marxista ao considerar qualquer fragmento da cultura capaz de indicar o modo de funcionamento da superestrutura e a dependência daquele em relação a esta. Tais fragmentos aparecem justamente sob a forma de imagens dialéticas, que, no sistema capitalista, revelam suas promessas de satisfação e, ao mesmo tempo, a anulação desta, pelo caráter sistêmico de seu funcionamento econômico.

Percebe-se que recuperar o sentido que permanecia esquecido tem uma função, tanto na psicanálise freudiana como na filosofia de Benjamin. Para este, "o passado leva consigo um índice secreto pelo qual ele é remetido à redenção.” (BENJAMIN, 1940/2005, p.48). Para falar especificamente das palavras soterradas pelo discurso oficial da história, é interessante retomar as palavras do filósofo: "Não ressoa nas vozes a que damos ouvido um eco das que estão, agora, caladas?" (idem). A enigmática tese $\mathrm{V}^{1}$ indica o caminho trilhado por Benjamin para pensar numa forma de redimir o passado da calamidade que o acomete. Como vimos, os êxitos da civilização carregam consigo uma boa dose de barbárie, que não pode ser soterrada. Desta forma, Benjamin concebe uma noção de tempo que permita, no presente, restituir ao passado o que lhe foi recusado. Lemos na tese VI:

“Articular o passado historicamente não significa conhecê-lo "tal como ele propriamente foi”. Significa apoderar-se de uma lembrança tal como ela lampeja num instante de perigo. Importa ao materialismo-histórico capturar uma imagem do passado como ela inesperadamente se coloca para o sujeito histórico no instante do perigo." (BENJAMIN, 1940/2005, p.65)

\footnotetext{
${ }^{1}$ A verdadeira imagem do passado passa célere e furtiva. É somente como imagem que lampeja justamente no instante de sua recognoscibilidade, para nunca mais ser vista, que o passado tem de ser capturado. "'A verdade não nos escapa' — esta frase de Gottfried Keller indica, na imagem que o Historicismo faz da história, exatamente o ponto em que ela é batida em brecha pelo materialismo histórico. Pois é uma imagem irrestituível do passado que ameaça desaparecer com cada presente que não se reconhece como nela visado." (BENJAMIN, 1940/2005, p.62).
} 
Não podemos esquecer a influência de Proust na obra de Walter Benjamin. Aqui há uma clara referência à memória involuntária; esta, ao ser capturada, pode redimir o passado desprezado. Na obra Em busca do tempo perdido (1913/2001), torna-se evidente que o tempo remoto não pode ser acessado por mecanismos voluntários da consciência, mas é evocado no encontro casual com alguma matéria ou algum objeto que resguarda uma lembrança. Se algo que me remete a um tempo morto não aparece, devo resignar-me perante o esquecimento ou morte do que sucedeu. Depende, por conseguinte, do acaso a emersão da memória, e não de francos esforços de inteligência. De acordo com Gagnebin (2006, p.152-3), Benjamin questionou a dependência do destino para evocar o passado, sugerindo que deveríamos construir possibilidades para encontrar o ponto de cruzamento entre o passado e o instante atual. Isto porque, em Benjamin, a memória involuntária ganha uma conotação política, visando explodir a continuidade do discurso oficial. Imergir num momento efêmero capaz de evocar os estilhaços varridos da história para que estes possam ser restaurados é a tarefa do materialista-histórico. Neste ponto, não nos aproximamos justamente do processo psicanalítico? A regra básica da psicanálise pode ser precisamente um meio de provocar a emersão desses acasos que convocam aspectos recalcados. A respeito de Proust, afirma Gagnebin:

\footnotetext{
"Na obra de Proust [...] [o acaso] é aquilo que não depende de nossa vontade ou de nossa inteligência, algo que surge e se impõe a nós e nos obriga, nos força a parar, a dar um tempo, a pensar - como faz o gosto da madeleine. Ao mesmo tempo, ele só pode ser percebido se há um treino, um exercício, uma ascese da disponibilidade, uma "seleção", umas "provas" que tornam o espírito mais flexível, mais apto a acolhê-lo, esse imprevisto, essa ocasião — kairos! — que, geralmente não percebemos, jogamos fora, rechaçamos, recalcamos.” (2006, p.153-4)
}

Aqui vemos ser necessária uma sensibilização para que estes aspectos, abandonados pela consciência como dejetos, sejam experimentados ou até mesmo percebidos. Os sonhos seguem um curso paralelo: “um desejo consciente só consegue tornar-se instigador do sonho quando logra despertar um desejo inconsciente do mesmo teor e dele obter reforço" (FREUD, 1900/1996, p.582). Tais desejos permanecem em estado constante de alerta prontos a concatenarem-se a um fragmento consciente do presente que os possa expressar, ainda que disfarçadamente. A memória involuntária proustiana se assemelha ao que Freud descreve como sendo o estado que precede o adormecimento. Diz ele:

\footnotetext{
“Ao adormecermos, surgem 'representações involuntárias', graças ao relaxamento de certa atividade deliberada (e, sem dúvida também crítica) a que permitimos influen-
} 
ciar o curso de nossas representações enquanto estamos acordados. (Costumamos atribuir esse relaxamento à 'fadiga'.) À medida que emergem, as representações involuntárias transformam-se em imagens visuais e acústicas. No estado utilizado para a análise dos sonhos e das ideias patológicas, o paciente, de forma intencional e deliberada, abandona essa atividade e emprega a energia psíquica assim poupada (ou parte dela) para acompanhar com atenção os pensamentos involuntários que então emergem, e que - e nisso a situação difere da situação do adormecimento - retêm o caráter de representações. Dessa forma, as representações "involuntárias” são transformadas em “voluntárias.” (FREUD, 1900/1996, p.136-7)

Entretanto, a atitude de espírito necessária para embarcar no relato de conteúdos oníricos que pareçam surgir de improviso, bem como o abandono da função crítica que normalmente atua contra eles, parecem tarefas difíceis de serem alcançadas. Isto porque tais “pensamentos involuntários” podem liberar uma resistência muito violenta, que procura impedir seu surgimento. Cabe ao analista resgatar esses elementos aparentemente destituídos de importância para sinalizar um conflito inconsciente. É interessante notar como o trabalho do analista, tanto na interpretação dos sonhos, como de aspectos sintomáticos, foca-se justamente nos restos, naquilo que fora subestimado pelo paciente. O psicanalista recorta tais sobras, que ficavam quase sem palavras no discurso do paciente, para dar-lhes nova sonoridade. Algo vago, impreciso, esquecido, recalcado, ganha matéria, corpo ao figurar na narrativa do paciente.

Neste sentido é que podemos retomar o cinema, por meio do qual é possível arrancar vestígios anônimos do cotidiano para colocá-los em cena. A questão que surge é: como a técnica cinematográfica, que na visão benjaminiana causa a morte da autenticidade e do aqui e agora próprios de obras de arte ainda envolvidas pela aura, pode remeter ao trabalho psicanalítico?

De acordo com a ideia de Walter Benjamin, a aura emana de um enigma que envolve o objeto, como se este estivesse encoberto por um véu translúcido ou por um estojo. A distância intransponível, imposta pelo véu, interdita o desvelamento total do objeto e arma um jogo dialético entre sua revelação e seu ocultamento, diante do qual o sujeito se enreda, procurando aproximar-se do que está fora de seu alcance. Compreende, além disso, uma unicidade e uma inacessibilidade do objeto por ela envolvido, que têm a paradoxal peculiaridade de transformá-lo em símbolo de uma experiência possível do que é inacessível. Ela é, assim, "a aparição única de uma coisa distante, por mais perto que ela esteja." (BENJAMIN, 1935-6/1994, p.170).

O conceito de aura aplica-se em diferentes contextos da filosofia benjaminiana, mas, principalmente, refere-se ao culto da obra de arte, que ocupou o lugar antes concedido ao culto religioso. Isto porque o caráter único e irreprodutível 
das obras resguarda, em sua materialidade, o instante de criação do artista, que precisamente se vincula ao momento de manifestação de sua genialidade e de um evento sublime - a própria criação — ligado, por conseguinte, a algo que transcende a racionalidade comum. Daí a comparação do culto religioso com a apreciação de obras.

Para Benjamin, a aura da obra de arte se esfacela na técnica de reprodução do cinema e da fotografia justo por libertar o objeto reproduzido do domínio da tradição. A multiplicação da reprodução coloca, no lugar da ocorrência única, o acontecimento em massa. Assim, romper o invólucro que envolvia o objeto, isto é, estilhaçar sua aura, aponta para características de uma percepção cuja semelhança é enfatizada a ponto de tornar os diferentes fenômenos eventos com sentidos unívocos e repetitivos. Por outro lado, a reprodutibilidade técnica da obra de arte a emancipa, pela primeira vez na história do mundo, de sua existência parasitária no ritual. A fotografia e a câmera de filmagem podem, por exemplo, salientar aspectos do original acessíveis apenas pela lente regulável, multiplicando infinitamente as possibilidades de perspectivas a que o olhar pode ter acesso. Ademais, a capacidade de reprodução artificial das máquinas transpõe cenários, sons, personagens, para lugares bem distantes de sua aparição original. Walter Benjamin demonstra isto quando diz: "A catedral abandona seu lugar para instalar-se no estúdio de um amador; o coro, executado numa sala ou ao ar livre, pode ser ouvido num quarto.” (1935-6/1994, p.168). Não é preciso dizer que hoje esta realidade vai bem além da gravação sonora ou de uma imagem fotográfica. Paul Valery (citado por BENJAMIN, 1955/1983) antevia o que na atualidade se tornou usual:

“Tal como a água, o gás e a corrente elétrica vêm de longe para as nossas casas, atender às nossas necessidades por meio de um esforço quase nulo, assim seremos alimentados de imagens visuais e auditivas, passíveis de surgir e desaparecer ao menor gesto, quase a um sinal.” (BENJAMIN, 1955/1983, p.6)

Estamos imersos em um mundo que disponibiliza facilmente imagens oníricas que podem ser compartilhadas para no momento seguinte se dissiparem, não pela mesma razão dos sonhos, mas pela questão do tempo que se impõe aos homens modernos. Os sonhos são esquecidos com facilidade e tornam-se ruínas, fragmentos quase indescritíveis. A velocidade de nosso mundo exige processo semelhante de nosso aparelho psíquico, que deve esquecer rapidamente o que acabou de se apresentar ou se formar para dar lugar a uma nova enxurrada ou bloco de afazeres ou pensamentos.

Ora, uma análise não é também uma reprodução artificial, que se dá por meio da neurose de transferência, de uma relação que tem no infantil sua força? 
Ao reinstaurar os afetos infantis na transferência com o analista, o paciente amplia os modos de expressar aquilo que se limitava a uma única maneira de representação. Logo, é possível afirmar que, com a psicanálise, as cenas são olhadas sob novas perspectivas, assim como ocorre com o cinema. É importante lembrar, contudo, que nem no caso da arte técnica ou na psicanálise trata-se de uma repetição tal e qual: não é o mesmo ouvir um coral ao ar livre e ouvi-lo em um quarto deitado na cama. Também com o analista, o paciente revive seus afetos infantis com toda sua carga afetiva, mas não se trata de uma reprodução ipsis litteris. Da mesma forma como a arte se modificou com a possibilidade de reprodução, e o sentido que se pode atribuir às obras de arte é outro após o advento da fotografia ou da gravação, o modo pelo qual vemos os episódios da vida psíquica jamais será o mesmo após o advento da psicanálise. As artes e a própria subjetividade não passam incólumes a estas duas marcas da cultura — a técnica cinematográfica e a criação da psicanálise. Pode-se, inclusive, perguntar se a Traumdeutung não teve para o sentido dos sonhos papel análogo ao advento da fotografia, e posteriormente do cinema, para as artes modernas. Em palavras mais precisas: não teriam os sonhos perdido sua aura? Na Ilíada, os sonhos figuram como previsão determinante para a guerra: não fosse o sonho de Agamêmnon, a famosa batalha de Troia jamais teria acontecido. ${ }^{2}$ Neste sentido, na antiguidade arcaica grega, o sonho ligava-se ao cosmos; havia uma comunhão entre os homens, as divindades e os sagrados sinais da natureza. A continuidade entre as decisões humanas, a interferência divina e as manifestações naturais colocava os sonhos como forma sagrada de comunicação entre estes aspectos, agora apenas vistos de forma segmentada.

Sabemos como na modernidade o sagrado foi substituído definitivamente pela ciência. Mas o cinema guarda uma semelhança com os procedimentos psicanalíticos ao embrenhar arte e ciência. No caso do cinema, Benjamin (1955/1983) esclarece que este inaugura um modo específico de o homem apresentar-se ao aparelho, mas, principalmente, trata-se de uma forma introduzida, graças ao aparelho de filmagem, de ele apresentar para si o mundo que o rodeia. A respeito daquele, diz Benjamin:

\footnotetext{
${ }^{2} \mathrm{Na}$ Idade Média, os sonhos ainda têm uma relação íntima com a divindade e a vida dos sujeitos (LIBERA, 1991/1999, p.250-1). Já no século XVII, ainda que os sonhos resguardem uma conexão com Deus, eles são pura ilusão, fantasia ou até uma espécie de teatro, podendo ser comparados com a vida humana: vã, passageira e ilusória. Esta visão a respeito da vida como sonhos pode ser ilustrada por meio da peça de Calderón, A vida é sonho. Nela lemos: "Que é a vida? Um frenesi, /Que é a vida? Uma ilusão,/uma sombra, uma ficção;/o maior bem é tristonho,/porque toda a vida é sonho/e os sonhos, sonhos são" (CALDERÓN, 1635/2008, p.73).
} 
"Esse fato - e é daí que provém a sua importância capital — tende a favorecer a mútua compenetração da arte e da ciência. Na realidade, quando se considera uma estrutura completamente ajustada ao âmago de determinada situação (como o músculo no corpo), não se pode estipular se a coesão refere-se principalmente ao seu valor artístico, ou à exploração científica passível de ser concretizada. Graças ao cinema - e aí está uma das suas funções revolucionárias - pode-se reconhecer, doravante, a identidade entre o aspecto artístico da fotografia e o seu uso científico, até então amiúde divergentes.” (1955/1986, p.22)

Na leitura de muitos escritos de Freud, temos sensação parecida: não sabemos ao certo se o autor, que inspirou surrealistas e recebeu o prêmio Goethe de literatura, seduz pela beleza de seu estilo ou se pelos resultados alcançados por seus métodos de tratamento. Se por um lado, encontramos na obra freudiana menções a Goethe, Schelling, Schnitzler, Shakespeare, dentre outros, não por acaso a figura do cirurgião é metáfora das delicadas intervenções do psicanalista, em diversas partes de sua obra. A precisão, a sofisticação de cada gesto interventivo, a racionalidade das decisões, o conhecimento empírico do corpo humano e os procedimentos que alteram a textura deste, só podem ter na ciência sua base. O cirurgião é também evocado por Benjamin para falar do cinema. Diz Benjamin que o cirurgião ${ }^{3}$ opõe-se ao mago cujo procedimento para alcançar a cura se dá por um toque no paciente, diferentemente do cirurgião, que de fato penetra em seu interior. Assim, o operador de câmera, como o médico-cirurgião, interfere profundamente na textura da realidade, recortada em infinitos e variados fragmentos, apenas conjugados por uma nova lei: a montagem. No caso

\footnotetext{
${ }^{3}$ A comparação entre a tarefa própria ao psicanalista e a do cirurgião aparece em alguns textos freudianos. Em Recomendações aos médicos que exercem psicanálise, contudo, nota-se que Freud faz ressalvas ao estabelecer esta analogia. Diz ele: "Não posso aconselhar insistentemente demais os meus colegas a tomarem como modelo, durante o tratamento psicanalítico, o cirurgião, que põe de lado todos os sentimentos, até mesmo a solidariedade humana, e concentra suas forças mentais no objetivo único de realizar a operação tão competentemente quanto possível. Nas condições atuais, o sentimento mais perigoso para um psicanalista é a ambição terapêutica de alcançar, mediante este método novo e muito discutido, algo que produza efeito convincente sobre outras pessoas. Isto não apenas o colocará num estado de espírito desfavorável para o trabalho, mas torná-lo-á impotente contra certas resistências do paciente, cujo restabelecimento, como sabemos, depende primordialmente da ação recíproca de forças nele. [...]. Um cirurgião dos tempos antigos tomou como divisa as palavras: "Je le pansai, Dieu le guérit.' O analista deveria contentar-se com algo semelhante.” (1912/1996, p.128). A advertência para que não se tome o cirurgião como modelo ocorre, neste caso, justamente devido a referências anteriores, que poderiam sugerir uma aproximação sem distinções. Mas a menção não aparece por acaso. O mesmo pode ser dito sobre W. Benjamin, que acrescenta longa nota para comparar o operador de câmara ao cirurgião, argumentando que "as dificuldades do filmador são, com efeito, comparáveis àquelas do cirurgião" (BENJAMIN, 1955/1983, p.20).
} 
da psicanálise, tal infiltração profunda fica patente, por exemplo, na análise de sonhos ou atos falhos. Nestes, uma palavra pode ser dita de forma equivocada, mas sua tessitura inédita tem seu sentido revelado na decomposição feita pelo trabalho psicanalítico.

Vale lembrar que, ao nos referirmos ao sonho, estamos inevitavelmente atrelados ao passado. Profere-se sempre: - Tive um sonho... No presente, o que resta são suas ruínas, fragmentos que preenchemos com palavras, tentando reconstituir as imagens originais. No cinema, o processo de produção de um filme também é diverso de seu resultado final, mas, ao contrário dos sonhos, são as partes desconexas que antecedem o todo imagético. Além disso, no caso do sonho, sua totalidade é singular e deste modo irreprodutível, enquanto o que caracteriza o cinema é justamente sua reprodutibilidade. Por outro lado, o sonho impõe-se ao sujeito paralisado e retirado do mundo externo, tal qual o efeito que um filme imprime em seus espectadores. O próprio ator assume feições para ele imprevisíveis diante da estranheza que o equipamento, sob a manipulação do diretor, capta. O ator age, mas é alheio aos seus gestos, expressões e falas. É como se representasse por meio de um fantasma de si mesmo. A imagem encarnada do teatro abandona o ator, que agora se vê diante de uma câmera tentando inutilmente vislumbrar a reação do público diante de imagens que nem mesmo pode saber como ficarão compostas. Para o intérprete, trata-se, como diz Pirandello (citado por Benjamin), do mesmo tipo de estranheza que se sente perante a própria imagem refletida no espelho, com a diferença de que agora tal imagem destaca-se da pessoa para ser transportada para as telas de cinema diante do público. ${ }^{4}$ É curiosa a menção feita ao espelho, que, no lugar de psicanalistas, nos faz subitamente pensar no caráter narcísico existente na atividade de representação dos atores de cinema. Os sonhos trazem justamente "um isolamento quase total do mundo ambiente e [...] uma suspensão de todo interesse por ele” (KAUFMANN, 1996, p.481), havendo uma extraordinária aproximação com a situação que foi o início do desenvolvimento de sua vida. Tais pensamentos freudianos sobre uma regressão temporal, que reconduziria a libido a um narcisismo primitivo e o eu a um estágio original correlativo de satisfação alucinatória referem-se à teoria dos processos pulsionais que condicionam os

\footnotetext{
${ }^{4}$ Se pensarmos nos processos para a constituição de um filme, vemos os atores, mas não só, sempre apartados da totalidade de sua ação que fica isolada e remete-se a um imaginário sobre um suposto público que assistirá aos resultados inacessíveis. Enquanto no teatro a atuação sofre o impacto do público e os atores procuram dançar no ritmo de seus pares de palco, no cinema o público está ausente e a ação de cada um dos atores não necessariamente acontece em conjunto. Pode haver em uma cena recortes e um ator é filmado após o outro para só posteriormente compor a cena como um todo, que será o trabalho do editor ou diretor. O contato com público só se faz por meio da fantasia, essencialmente narcísica.
} 
sonhos. Nestes parece haver uma retirada de investimento de representações objetais, denominada por Freud "narcisismo do estado do sono" (idem, p.482).

Para Freud, no princípio o aparelho psíquico reunia todos os seus esforços a fim de manter-se livre de estímulos. Descarregava, desta forma, qualquer excitação sensorial por uma via motora. Há, contudo, um desenvolvimento posterior do aparelho, decorrente das exigências da vida, que altera a permanente força interna de excitação por meio de uma intervenção externa que propicia uma "vivência de satisfação". O bebê chora, dá pontapés devido à incidência da excitação interna provinda de uma necessidade e daí advém um auxílio externo, que aplaca o estímulo interno. A vivência de satisfação é, por conseguinte, uma "percepção específica, cuja imagem mnêmica fica associada, daí por diante, ao traço mnêmico da excitação produzida pela necessidade." (FREUD, 1900/1996, p.594). Assim, na reincidência da necessidade emergirá imediatamente uma moção psíquica que buscará investir a imagem mnêmica da percepção e reevocar a própria percepção, restabelecendo a situação da satisfação original.

Tal moção é o que a psicanálise reconhece como desejo, e o ressurgimento da percepção satisfatória é a própria realização do desejo, sendo o caminho mais curto para tal realização a completa catexia da percepção. Vemos que a tentativa do aparelho é a de reproduzir de forma alucinatória a percepção vinculada à satisfação da necessidade. Mas a "amarga experiência da vida" (idem, p.595) tocou de forma irremediável esta atividade primitiva de pensamento, transformando-a em uma atividade secundária mais conveniente, qual seja, a satisfação advinda do mundo exterior. Assim, foi necessário deter a regressão em direção à imagem mnêmica para que a busca por outros caminhos capazes de restabelecer a desejada identidade perceptiva pudesse ocorrer desde o mundo exterior. É desta maneira que a "inibição da regressão e o subsequente desvio da excitação passam a ser da alçada de um segundo sistema, que controla o movimento voluntário - isto é, que pela primeira vez se vale do movimento para fins lembrados de antemão" (idem).

Sendo assim, Freud considera que toda a sinuosa atividade de pensamento que vai da imagem mnêmica até a identidade perceptiva estabelecida pelo mundo exterior é um percurso indireto para a realização de desejo. Logo, o que temos é uma substituição pelo pensamento do que era um desejo alucinatório. Desta forma, os sonhos são realizações de desejos, pois somente estes colocam nosso aparelho psíquico em ação. No caso específico dos sonhos, é possível afirmar que eles mantêm uma forma primitiva de realização do desejo, isto é, esta ocorre pela regressão ao traço mnêmico satisfatório, reconstituindo-o de forma alucinatória. Por isso, Freud afirma: "O sonho é um ressurgimento da vida anímica infantil já suplantada" (1900/1996, p.596) 
Ora, o cinema não seria, como já mencionado no início do texto, uma alucinação compartilhada? Reconstituímos os sonhos, agora pela via mais evoluída de nosso aparelho psíquico, e a identidade perceptiva desde o mundo exterior aproxima-se de maneira cada vez mais fidedigna da alucinação tal como esta se dá na vida anímica infantil.

Assim, se por um lado o cinema reproduz os choques vividos pelo homem moderno nas cidades, por outro, é capaz de reconduzir o sujeito à sua vida anímica mais primitiva, podendo, muitas vezes, restaurar aspectos órfãos de elaboração psíquica. O mesmo paradoxo pode ser evidenciado no processo psicanalítico e na interpretação dos sonhos, pois, ainda que o projeto freudiano de análise do inconsciente esteja pautado em modelos e critérios erguidos na modernidade, o simples fato de resgatar sonhos do limbo, concedendo-lhes importância diferentemente do que vinham fazendo as ciências - revoluciona os próprios critérios e procedimentos modernos. Ao dar voz ao inconsciente, observa-se a lógica da modernidade em ação, mas sua simultânea recusa, o que produz efeitos transformadores na subjetividade moderna. Filmes como os de David Lynch, Bergman ou Fellini provam que imagens oníricas - ou o inconsciente de alguns sujeitos — finalmente puderam ganhar espaço e vagar mundo afora.

\section{REFERÊNCIAS}

BENJAMIN, W. (1935-6/1994). "A obra de arte na era de sua reprodutibilidade técnica” (1 $1^{\mathrm{a}}$ versão, P. S. ROUANET, trad.), in BENJAMIN, W. Obras escolhidas. São Paulo: Brasiliense.

(1939/1997) "Sobre alguns temas em Baudelaire" (J. M. Barbosa, H. A. Batista, trad.), in BENJAMIN, W. Obras escolhidas. São Paulo: Brasiliense (Trabalho original publicado em 1939).

(1950/1983) "A obra de arte na era de sua reprodutibilidade técnica” ( $2^{\mathrm{a}}$ versão), in BENJAMIN, W. Os pensadores. São Paulo: Abril Cultural.

(1940/2005) "Sobre o conceito de história” (J. M. GAGNEBIN, trad.), in LÖWY, M. Walter Benjamin: aviso de incêndio. São Paulo: Boitempo. BERNARDET, J.-C. (1980) O que é cinema. São Paulo: Brasiliense.

CALDERÓN, (1965/2008) A vida é sonho. (R. Pallottini, trad.) São Paulo: Hedra.

FREUD, S. (1996) Obras completas brasileiras. Rio de Janeiro: Imago.

(1900) “A interpretação dos sonhos”, v.I e II, p.15-721.

(1901) "Psicopatologia da vida cotidiana”, v.VI, p.19-236. 
(1912) "Recomendações aos médicos que exercem a psicanálise" v.XII, p.125-136.

(1930) "O mal-estar estar na civilização", v.XXI, p.73-150.

GAGNEBIN, J.-M. (2005) Lembrar escrever esquecer. São Paulo: Editora 34.

KAUFMANN, P. (1996) Dicionário enciclopédico de psicanálise. Rio de Janeiro: Jorge Zahar Editor.

LIBERA, A. de (1991/1999) Pensar na Idade Média. São Paulo: Editora 34. PROUST, M. (1913/2001) Em busca do tempo perdido. Rio de Janeiro: Globo. MURICY, K. (1999) Alegorias da dialética. Rio de Janeiro: Relume Dumará. RIVERA, T. (2008) Cinema, imagem e psicanálise. Rio de Janeiro: Jorge Zahar Editor.

ROCHLITZ, R. (2003) A filosofia de Walter Benjamin: o desencantamento da arte. Bauru (SP): Edusc.

SAFATLE, V. (2008) Cinismo e falência da crítica. São Paulo: Boitempo.

Alessandra Affortunati Martins Parente aamparente@gmail.com 